University of Nebraska - Lincoln

DigitalCommons@University of Nebraska - Lincoln

USDA National Wildlife Research Center - Staff Publications
U.S. Department of Agriculture: Animal and Plant Health Inspection Service

2010

\title{
The Earliest House Sparrow Introductions to North America
}

\author{
Michael P. Moulton \\ University of Florida \\ Wendell P. Cropper Jr. \\ University of Florida \\ Michael L. Avery \\ USDA Wildlife Services, Florida, michael.I.avery@aphis.usda.gov \\ Linda E. Moulton \\ University of Florida
}

Follow this and additional works at: https://digitalcommons.unl.edu/icwdm_usdanwrc

Part of the Environmental Sciences Commons

Moulton, Michael P.; Cropper, Wendell P. Jr.; Avery, Michael L.; and Moulton, Linda E., "The Earliest House Sparrow Introductions to North America" (2010). USDA National Wildlife Research Center - Staff Publications. 961.

https://digitalcommons.unl.edu/icwdm_usdanwrc/961

This Article is brought to you for free and open access by the U.S. Department of Agriculture: Animal and Plant Health Inspection Service at DigitalCommons@University of Nebraska - Lincoln. It has been accepted for inclusion in USDA National Wildlife Research Center - Staff Publications by an authorized administrator of DigitalCommons@University of Nebraska - Lincoln. 


\title{
The earliest House Sparrow introductions to North America
}

\author{
Michael P. Moulton • Wendell P. Cropper Jr. • \\ Michael L. Avery $\cdot$ Linda E. Moulton
}

Received: 8 December 2009/ Accepted: 7 January 2010

(C) Springer Science+Business Media B.V. 2010

\begin{abstract}
Several authors have argued that three separate introductions of roughly 100 individuals were required initially to establish the House Sparrow (Passer domesticus) in the Brooklyn, New York area. We argue that these claims are in error and that the actual record suggests that it is likely the initial introduction of just 16 birds in 1851 was all that was required to establish the species in New York. We further suggest that a similar level of scrutiny of historical records will reveal more examples of misinterpretations and errors, casting doubt on the validity of studies that claim propagule pressure has played an important role in determining the fate of bird introductions.
\end{abstract}

Keywords House Sparrow · Historical records . Propagule pressure

Several studies of avian introductions have used 'historical records' to conclude that introduction effort has been a principal factor associated with

M. P. Moulton $(\square)$ · W. P. Cropper Jr. · L. E. Moulton University of Florida, Florida, USA

e-mail: moultonm@ufl.edu

M. L. Avery

USDA Wildlife Services, Florida, USA introduction success (e.g., Veltman et al. 1996; Duncan 1997; Green 1997; Cassey 2003; Cassey et al. 2004; Lockwood et al. 2005; Duncan et al. 2006). The validity of these conclusions hinges on the accuracy of records that purport to document introduction effort. Here, we argue against uncritical reliance on such 'historical records' and we use the story of the earliest House Sparrow introductions to North America to illustrate our concerns.

Long (1981) cited Wetmore (1964) and Robbins (1973) when he reported that the House Sparrow (Passer domesticus) was initially brought to Brooklyn, New York in 1850, but not actually released until 1851. Long (1981) cited Roberts (1960) as reporting that the initial introduction, conducted by the Brooklyn Institute, was unsuccessful. Long (1981) cited Robbins (1973) as reporting that 'about 100' sparrows were subsequently brought from England in 1852, with 50 of these being released at the Narrows and the rest released in 1853 at the Greenwood Cemetery. Finally, Long (1981) cited Silverstein and Silverstein (1974) as saying that this last release (1853) was actually the first successful introduction of the House Sparrow in the United States. Roberts (1960), Wetmore (1964), Robbins (1973), and Silverstein and Silverstein (1974) simply restate the account by Barrows (1889). Similarly, Lever (1987) restated most of the original Pike quotation in Barrows (1889), as did Anderson (2006).

In the 1880s, many people in the United States were convinced that the House Sparrow was a serious 
pest to agriculture and to native species of birds (Barrows 1889). Others disagreed with this assessment (Barrows 1889). The monumental task of deciding the truth regarding the status of the House Sparrow, friend or foe, fell to ornithologist C. Hart Merriam and assistant ornithologist Walter Bradford Barrows of the U.S. Department of Agriculture's Division of Economic Ornithology and Mammalogy. To accomplish their task, they designed a study that involved sending out "upwards of 5,000 copies" of a special circular, the goal of which was to gather information on the distribution, abundance and habits of the House Sparrow around the country. So at the outset, we note that Barrows (1889) is actually a compilation itself of 3,300 responses from the general public.

Among the respondents to Barrows' 'circular' was Nicholas Pike (Barrows 1889). Pike informed Barrows, that he had been associated with the first reported introductions of House Sparrows in the United States in the 1850s. Barrows (1889) quoted Pike, as stating that the first recorded importation of House Sparrows in the United States occurred in the fall of 1850 when eight pairs of House Sparrows were brought to Brooklyn, New York from England, kept in cages until the spring of 1851 , and then released (Barrows 1889). Barrows further quoted Pike as reporting that these birds, when released, "did not thrive". Most likely this simply means that the birds were not seen again.

In 1850, Nicholas Pike was the director of the Brooklyn Institute (Barrows 1889), so we have every reason to believe that he had direct knowledge of this first introduction. Thus, Pike's report to Barrows constitutes an actual historical record, of sorts. Unfortunately, there are inconsistencies in the rest of Pike's story.

Barrows (1889) quoted Pike as saying that he (i.e., Pike) subsequently chaired a three-member committee in 1852 for the "re-introduction of these birds". In the meantime, Pike was appointed Consul General to Portugal. He sailed to England in 1852, and in Liverpool claimed he ordered, "a large lot of Sparrows and song birds..." (Barrows 1889).

According to Pike, these birds were shipped to New York aboard the steamship Europa, and 50 sparrows were purportedly released at the Narrows. What actually transpired is unknown because Pike, en route to Portugal, was apparently not aboard the
Europa and did not witness any releases. The remaining sparrows, the exact number of which is not mentioned in the Barrows (1889) quotation of Pike's notes, were reportedly placed in a tower at the Green-Wood Cemetery Chapel in Brooklyn. Those birds apparently did not do well and so were taken to the private residence of John Hooper a member of the abovementioned three-member committee formed in 1852.

So according to Barrows (1889), by Pike's account, more than 66 House Sparrows (perhaps as many as 116 in total-the initial 8 pairs, plus one lot of 50 released at the Narrows and another of as many as 50 at Greenwood Cemetery), in three separate releases took place by 1853 . Robbins (1973) repeated the Pike quotation found in Barrows (1889) that the first 16 birds "did not thrive", and he repeated the listing in Table I of Barrows (1889) that states that "about 100" more House Sparrows were released by 1853. Actually Table I of Barrows (1889) is unclear as it lists a total of 100 individual House Sparrows as being released in 1851 and 1852 .

Phillips (1928) reported that "a large number" of House Sparrows were released at Greenwood Cemetery in the spring of 1853 , and claimed that the account was written by Nicholas Pike, but cited no reference. Indeed, Phillips (1928) claimed that references to early House Sparrow introductions to the United States were "too numerous to cite". It is unclear where Phillips (1928) obtained his information, but we believe his information likely came from the quotations of Pike by Barrows (1889).

Closer examination of these reports and their origins reveals that the actual numbers of individuals initially released are unknown beyond the 16 sparrows released in 1851. John Hooper, a member of the abovementioned committee, presented a report on the experimental bird introductions at Greenwood Cemetery to a meeting of the American Institute of the City of New York (Hooper 1854). Hooper does not mention sparrows anywhere in the report. Likewise, in his history of the Greenwood Cemetery, Cleaveland (1866) listed the same bird species as Hooper (1854) and makes no mention of any sparrows.

Thus, the only evidence that any House Sparrows were subsequently released in Brooklyn in the early 1850 s, after the initial 16 released under the direction of Nicholas Pike in 1851, is based on what appears to be Pike's 35 year old memory. Between 1852 and 
1861 Pike served as Consul General to Portugal (Kestenbaum 2009), and he was on his way to Portugal when he ordered the birds. Thus, there is no reason to believe that Pike was even aboard the Europa, the ship he claimed brought the sparrows to Brooklyn in 1852. If he wasn't on board, he could not have known what birds, if any, were actually released at the Narrows.

We must therefore reconsider the fate of the initially introduced 16 individuals. Perhaps additional releases were unnecessary for the establishment of the House Sparrow in the vicinity of New York. Conditions then were highly favorable to House Sparrows. Large numbers of horses (McShane and Tarr 2007; Greene 2008) accompanied by loads of spilled grain and tons of droppings filled with undigested grain provided ample food for House Sparrows (Doughty 1978). There is no reason to believe conditions were so harsh in the New York City area that 16 House Sparrows could not have survived.

It seems more plausible that the first birds simply went undetected after the initial release. In the nineteenth century people were limited as to where they could go to look for birds, and there were no published field guides available filled with color pictures of birds (Peterson 1934). Moreover in 1852, even if a person had seen and correctly identified an individual House Sparrow it is not obvious how the news would have been spread.

Using historical records as the basis for studies of ecological processes, such as the introduction outcomes of birds, can be problematic. As demonstrated by our discoveries regarding the earliest recorded introductions of the House Sparrow in North America, it is very difficult if not impossible to verify the exact circumstances surrounding a given introduction event. Even an oft-repeated, heretofore well-accepted species introduction story, such as that of the House Sparrow in New York, can turn out to be built on a foundation of non-existent data. The frequency with which similar unverifiable or untrue species invasion stories are incorporated as data points in analyses of the success or failure of species introductions is not known. We contend, however, that there is ample room for skepticism when historical records previously invoked as evidence to support a given perspective, namely studies of propagule pressure, on the fate of species invasions are revealed to be mere anecdotes.
Acknowledgments We thank Marilyn Howell at the National Wildlife Research Center for verifying some of the historical records.

\section{References}

Anderson TR (2006) Biology of the ubiquitous House sparrow: from genes to populations. Oxford University Press, Oxford, UK

Barrows WB (1889) The English sparrow (Passer domesticus) in North America, especially in its relation to agriculture. U.S. Department of Agriculture, Division of Economic Ornithology and Mammalogy Bulletin 1, pp 1-606

Cassey P (2003) A comparative analysis of the relative success of introduced land birds on islands. Evol Ecol Res 5:1011-1021

Cassey P, Blackburn TM, Sol D, Duncan RP, Lockwood JL (2004) Global patterns of introduction effort and the establishment success of birds. Proc R Soc Lond B (Suppl) 271:S405-S408

Cleaveland N (1866) Green-Wood Cemetery: a history of the institution from 1838 to 1864 . Anderson and Archer, New York

Doughty R (1978) The English sparrow in the American landscape: a paradox in nineteenth century wildlife conservation. Research papers, no. 19. Oxford Publishing Co., [for the] School of Geography, University of Oxford, Oxford

Duncan RP (1997) The role of competition and introduction effort in the success of passeriform birds introduced to New Zealand. Am Nat 149:903-915

Duncan RP, Blackburn TM, Cassey P (2006) Factors affecting the release, establishment and spread of introduced birds in New Zealand. In: Allen RB, Lee WG (eds) Biological invasions in New Zealand. Ecol Stud 186:137-154

Green RE (1997) The influence of numbers released and the outcome of attempts to introduce exotic birds to New Zealand. J Anim Ecol 66:25-35

Greene AN (2008) Horses at work: harnessing power in industrial America. Harvard University Press, Cambridge

Hooper J (1854) Entry for March 7, 1854 Assembly 150. Transactions of the American Institute of New York City 1853. pp 466-470

Kestenbaum L (2009) US Consuls to Portugal. http://political graveyard.com/geo/ZZ/PT.html. Accessed 2 Dec 2009

Lever C (1987) Naturalized birds of the world. Longman Scientific and Technical, Harlow, Essex

Lockwood JL, Cassey P, Blackburn T (2005) The role of propagule pressure in explaining species invasions. Trends Ecol Evol 20:223-228

Long JL (1981) Introduced birds of the world. David and Charles, London

McShane C, Tarr JA (2007) The horse in the city: living machines in the nineteenth century. The Johns Hopkins University Press, Baltimore

Peterson RT (1934) A field guide to the birds: giving field marks of all species found in eastern North America. Houghton Mifflin, New York

Phillips JC (1928) Wild birds introduced and transplanted into North America. US Dep Agric Tech Bull 61:1-63 
Robbins CS (1973) Introduction, spread, and present abundance of the House sparrow in North America. In: Kendeigh SC (ed) A symposium on House sparrow (Passer domesticus) and European tree sparrow (P. montanus) in North America. AOU Ornithological Monographs 14:3-9

Roberts TS (1960) Bird portraits on color, 1943, rev ed 1960. University of Minnesota Press, Minneapolis
Silverstein A, Silverstein V (1974) Animal invaders: the story of imported wildlife. Athenum, New York

Veltman CJ, Nee S, Crawley MJ (1996) Correlates of introduction success in exotic New Zealand birds. Am Nat 147:542-557

Wetmore A (1964) Song and garden birds of North America. National Geographic Society, Washington, DC 